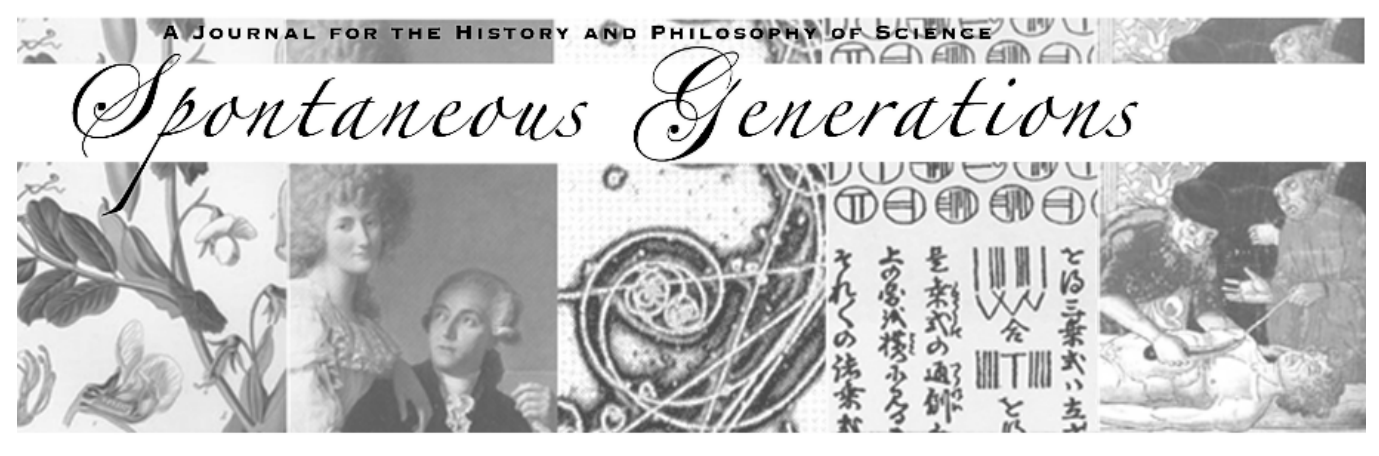

\title{
Why Do Stem Cells Create Such Public Controversy?
}

Author(s): Jane Maienschein

Source: Spontaneous Generations: A Journal for the History and Philosophy of Science, Vol. 5, No. 1 (2011) 27-35.

Published by: The University of Toronto

DOI: $\underline{10.4245 / \text { sponge.v5i1.15099 }}$

\section{EDITORIAL OFFICES}

Institute for the History and Philosophy of Science and Technology

Room 316 Victoria College, 91 Charles Street West

Toronto, Ontario, Canada M5S 1K7

hapsat.society@utoronto.ca

Published online at jps.library.utoronto.ca/index.php/SpontaneousGenerations ISSN 19130465

Founded in 2006, Spontaneous Generations is an online academic journal published by graduate students at the Institute for the History and Philosophy of Science and Technology, University of Toronto. There is no subscription or membership fee. Spontaneous Generations provides immediate open access to its content on the principle that making research freely available to the public supports a greater global exchange of knowledge. 


\title{
Why Do Stem Cells Create Such Public Controversy?*,
}

\author{
Jane Maienschein ${ }^{\ddagger}$
}

\begin{abstract}
Biological development is about history, the history of an individual through time. Historically, the dominant epigenetic tradition has seen the developmental process as an unfolding of potential or in terms of the emergence of new organization that becomes an individual organism over time. The concept of development has included differentiation, growth, and morphogenesis; since the mid-nineteenth century, it has been seen in terms of cell division. Along the way have come explorations of such issues as the extent to which development is driven by hereditary determination rather than flexible regulation in response to changing conditions. Some researchers have focused specifically on examining the capacity for regeneration in response to injury or loss, or on the extent to which parts are self-organizing individually rather than determined segments of a whole. This paper introduces the historical study of development.
\end{abstract}

\section{Biological Context}

For millennia, researchers have puzzled about embryos and studied embryology to investigate developmental changes. Development has been seen as continuing at least into adulthood and some have seen processes of aging, or senescence, as representing stages of continuing development. Others have included all developmental stages up to death and even into the next generation as development (on Ernst Haeckel's idea of “overgrowth," see Churchill 1968). More recently, developmental geneticists have emphasized the role of inherited determinants in defining developmental possibilities. Meanwhile, religious and social interpreters have offered other views.

* Thanks to the National Science Foundation for support, and to the University of Toronto community for valuable feedback on a talk that led to this paper.

$\dagger$ Received 23 March 2011.

$\ddagger$ Jane Maienschein is Regents’ Professor, President’s Professor, Parents Association Professor, and Director, Center for Biology and Society at Arizona State University. She specializes in the history and philosophy of biology and the way that biology, bioethics, and biopolicy play out in society. Focusing on research in embryology, genetics, and cytology, she combines detailed analysis of the epistemological standards, theories, laboratory practices, and experimental approaches with study of the people, institutions, and changing social, political, and legal context in which science thrives. She loves teaching and is committed to public education about biology and its human dimensions.

Spontaneous Generations 5:1 (2011) ISSN 1913-0465. University of Toronto. 
Here, I argue that stem cell research has created such a fuss because we do not have a shared public understanding of embryos. Yes, developmental biologists have a very good account of many aspects of the processes of development and are busily working on others. Yet, until very recently, they have not seen it as terribly important to make that understanding public or to worry about widely-accessible definitions. As a result, biological and social embryos have become different things, with the social interpretations conflicting with biological reality. It is important to understand how this has happened and why.

History of science helps give us that understanding, providing perspective on the co-existence of competing and sometimes conflicting views and uncovering underlying assumptions in social and biological interpretations. In the following essay, I do not intend to provide a fully developed and completely documented scholarly argument since I have done some of that work elsewhere. Instead, I provide a view of the history of embryology painted with perhaps ridiculously broad brush strokes in order to explore new interpretations of embryos in the twentieth and twenty-first centuries. I welcome comments and discussion.

\section{EARly History of EMbryos}

In the beginning came Aristotle, as is usual in the history of biology. Aristotle asked how the initially unformed could become formed. The interplay of Aristotelian causes gave him an explanatory framework, which was based on the empirical foundation that our experience shows us that an organism (like us) begins during sexual reproduction with the mixture of fluids from each parent. We can see that the earliest development stages are characterized by unformed material that only gradually becomes formed. To make this happen, it seemed that there must be some vital driving force or entity, although various alternative accounts appealed to different interpreters (for discussion and references on the general history of embryology, see Maienschein 2003).

This epigenetic interpretation persisted, and was actually the major view of development embraced by Catholic, Jewish, Islamic, and philosophical traditions into the late seventeenth and early eighteenth centuries. At that point, as historian Shirley Roe has shown, a few leading natural philosophers embraced a materialistic metaphysical view of the world (Roe 1981). Materialism was not compatible with vitalistic accounts, but it was difficult to see how form could arise from the unformed without some non-material and non-mechanical cause. Therefore, an alternative interpretation emerged and concluded that form must really be there from the beginning. On this view, development must begin with preformation rather than epigenesis.

This is an often-told story of epigenesis and preformation, vitalism and materialism (Bowler 1971). It is also a story of epistemology and metaphysics, since the epigenetic view started with the epistemological assumption that we do not see any form from the beginning, and as good empiricists we must trust our senses. 
Materialists started from metaphysical convictions.

Naturalists such as Caspar Friedrich Wolff and Charles Bonnet argued about what must be going on inside the developing chick egg, while Albrecht von Haller asserted that something so complex as the nervous system could not possibly arise by accident through epigenesis. Jan Swammerdam dissected the caterpillar to determine whether there was a butterfly somewhere inside and Abraham Trembley chopped up hydra and turned them inside out to see what he could learn about development from regeneration. This was a lively time for studying development, with great discoveries and deep differences in interpretation. The two main views that dominated debate until the late twentieth century were laid out then: preformation or epigenesis?

The nineteenth century brought many wonderful discoveries, including close study of cells and development of cell theory. Fertilization and the process of cell division provided an underlying basis for differentiation during processes of development and epigenetic views gained strength with each discovery. At least they gained strength among biologists, so that by the middle of the nineteenth century a materialistic biological understanding of the embryo was well underway.

Meanwhile, in 1869 Pope Pius IX declared that life begins at "conception," as part of a reform effort that would later be labeled Vatican I. He clearly meant that a person's individual life begins with conception, by which he seemed to have meant fertilization. With this assertion, he established a Catholic version of embryonic development that co-existed with, but did not conform to, the biological understanding of the embryo. Over time, this view increasingly seemed not even to care about biological understandings. Jewish and Muslim theologians remained epigenesists and saw the early developmental stages as "like water" and as undifferentiated. By the latter part of the nineteenth century, therefore, understanding of embryos began to diverge.

\section{EXPERIMENTAL EMBRYOLOGY}

By the late nineteenth century, researchers were busily studying cell division, cell lineage, and differentiation processes during development. Some felt that they were reaching the limits of what they could learn by observation alone and turned to manipulative experiments. With his call for Entwickelungsmechanik, Wilhelm Roux led the way in working to control the embryo in order to see what was going on inside. His well-known experiment with two-celled frog eggs has appeared in many biology textbooks as if it demonstrated the importance of inheritance. In fact, Roux took frogs eggs and destroyed one of two cells with a hot needle. He watched the other cell develop as a "half embryo" with the inert material from the destroyed cell just sitting there. Roux concluded from this that the embryo develops like a mosaic, with each cell having a pre-determined destiny and guided by "determinants." 
Then Hans Driesch showed that the cells in sea urchins could actually be shaken apart so that they were truly independent. In this case, the result was not half embryos but two smaller larval forms. Driesch concluded that this means that development is highly regulatory, signifying that it has the capacity to respond to changing environmental conditions. Roux responded that it must be the case that the embryo had a set of "auxiliary" heredity determinants that allowed the regeneration of the missing parts (for further discussion, see Maienschein 1991).

Roux's and Driesch's experiments enticed others to perform a closer analysis of just what happens in development and ask new questions: to what extent is each cell or each part already determined in its fate, to what extent is it "plastic" in its capacities, and is each cell normally determined but able to respond and change under some conditions? The period 1900-1930 brought enthusiastic study of regeneration (especially by Thomas Hunt Morgan), study of fate mapping (especially by Walter Vogt), study of what we can learn from transplantation (led by Hans Spemann and Ross Granville Harrison, whose transplantation of what we now know as neural stem cells led to the first successful tissue culture), and other attempts to discover how much is determined and how much is responsive in development.

\section{Biological and Social Views of Embryos}

The second half of the twentieth century brought a mix of biological and social factors that considerably complicate the understanding of embryos. Those who called themselves embryologists largely gave way to self-declared "developmental biologists." Developmental biologists typically looked at developmental genetics and either ignored traditional developmental questions about morphogenesis and differentiation or addressed those in terms of genetic expression.

1953 brought the double helical structure of DNA, of course, and also public awareness of the cloning of frogs through nuclear transplantation. Robert Briggs and Thomas King finally carried out the experiment that Spemann had suggested as "fantastical" in 1938 and published the results in 1952. They enucleated a frog egg and transplanted a nucleus from another egg into the host. The resulting development looked normal, though they could only get the experiment to work with donor nuclei from very early developmental stages. This led them to assume that the donor and host both had to be from the earliest developmental stages. John Gurdon's work in the 1960s showed that later stage embryonic nuclei could work as well (see Gurdon 1999 for a nice summary of this and subsequent cloning work).

This work on cloning is widely touted as a triumph of genetic determinism, and the story is often told in terms of substituting one set of nuclear determinants for another. But that wasn't the only story at the time, and when we look back we should also see excitement about the developmental result: it was possible to exchange the nuclear material without hindering the egg's capacity to develop! It 
could respond to even these extremely altered conditions. Epigenetic regulation in development is powerful indeed and, as Sarah Franklin has discussed, by the time we got to Dolly the sheep, many stories were mixed together (Franklin 2007).

In the 1960s, Beatrice Mintz further demonstrated the regulatory capacity (Mintz 1962). She took embryos from two different mouse strains and combined them, creating a chimera. Commentators today often point to the fact that the resulting mice were striped, which might suggest hereditary determinism as each set of cells expresses color true to inheritance. But what should be far more astonishing is that the whole process is possible. Taking cells from completely different embryos and mixing them together leads to an apparently healthy mouse that follows an apparently normal development. Regulatory epigenetic development prevails.

With research at the Jackson Laboratory starting in the 1950s and continuing into the 1970s, Leroy Stevens showed that a particular strain of mouse embryos gives rise to teratomas, with a mix of teeth, hair, and other tissue growing where it normally would not and should not-typically in the testes or the abdomen. He looked further and identified a cluster of cells that were not differentiating normally, but rather in a delayed way. He labeled the cells pluripotent stem cells (Stevens 1970).

This research all suggested that complex developmental processes involve interaction among cells and differentiating parts, in the context of environmental conditions that enable and constrain the possible outcomes. Heredity plays a role too, of course, but development is not primarily a matter of gene expression-that seemed obvious to development biologists. And, as a result, the embryo is a material cluster of cells that develop by differentiating only gradually and responsively. The form is not there from the beginning, nor is all the information needed to produce a healthy embryo.

Yet, the biological embryo remained largely invisible to the general public. A study of high school textbooks shows a concern for only a very broad understanding, sometimes packaged in terms of reproductive health and sometimes represented in terms of Ernst Haeckel's diagrams comparing different embryos-diagrams that had long been discredited in showing what the textbooks were using them to show (Wellner 2010; Maienschein and Wellner 2011). While some embryologists/developmental biologists had achieved public attention in earlier decades, after WWII, genetics received far more attention.

This left religious leaders to emphasize theological and metaphysical interpretations of embryos without any question from biologists. The Vatican position solidified around the "life begins at conception" theme and other conservative Christian churches began to adopt similar interpretations. The rise of birth control options and rise of abortion rights (culminating in the U.S. Supreme Court ruling in Roe v. Wade) gave religious leaders reasons to define when life begins for these practical and political reasons. 
By implication, human embryos have been defined as the earliest stages of an individual person's life. Embryos became associated with "conception" and, as a result, with the idea of the coming together of two genetic complements during fertilization. Embryos became clusters of inherited genetic material, and therefore the apparent union of two genomes at fertilization. Largely by accident, the enthusiasm for genetics and the understanding of DNA reinforced a conservative religious and social interpretation of embryos as almost preformed (or at least predetermined) little persons. This is highly problematic biologically, since the earliest stages remain highly plastic and responsive to changed conditions, as we have seen.

But developmental biologists did not see the social and political discussion as part of their domain or they did not see the need or appropriateness of addressing the social discussions in the context of biology textbooks (personal discussions with textbook authors Scott Gilbert, Paul Farber, Garland Allen). As a result, co-existing and incompatible views of embryos became established but the contradictions did not seem to bother either side tremendously.

The first birth relying on in vitro fertilization (IVF) should have raised more questions, and it did for Catholics and some others who declared that such procedures were morally illicit. In spite of these concerns, IVF has allowed the births of many thousands of babies who would not have been born otherwise, and there is a large constituency for the technology: merely wishing that IVF will go away will not make it do so. The first users of the technique saw themselves as helping development along, but such a statement is difficult to sustain today. With pre-implantation genetic diagnosis since 1990, where one or two cells are removed from an eight stage embryo and are tested for genetic "diseases," it has become clear that the results by Briggs and King on cloning and by Mintz on chimeras hold: development is epigenetic, highly responsive to changing conditions, and the stages of embryos are very, very different from each other.

This emphasis on epigenesis takes us back to the late nineteenth and early twentieth centuries, when researchers studying a variety of different organisms mapped out the developmental stages (see especially Hopwood 2000). We have known for a very long time that there are different developmental stages, with each bringing greater determination of characteristics and less plasticity. We have known for a very long time that there are sometimes genetic "predispositions" that run in families, but that can be controlled by managing the environment-diet, exercise, or other factors. In fact, much of the medical emphasis for expectant mothers has focused on what they can do to manage a healthy gestation for their embryo/fetus/baby. What they eat, do, or even think about may make a difference, and the embryo (as it is called in humans up until the eight week stage) is especially susceptible to alcohol and other ingested substances. We are learning more and more about such factors, but have known for at least a century that such impacts exist (Pauly 1996). 
Thus, by the second half of the twentieth century, a mix of different views co-existed and at times competed with different background assumptions not even articulated. A biological understanding of embryos emphasized gradual development responding to hereditary factors and environmental conditions. Religious interpretations varied from the traditional epigenetic Jewish view to the hereditary determinism of Catholics. Social views of embryos were a mix between these interpretations. Metaphysical convictions have also mixed with empirical and epistemological assumptions. By the end of the twentieth century, we had a range of more epigenetic and more preformationist views, with greater or less emphasis on epistemological empiricism or on metaphysics.

\section{A Third View through Technology: Constructing and Synthesizing}

Since 1997, a third-and very different-view of embryos has emerged. This is likely to expand significantly with developments in synthetic biology. It was in 1997 that lan Wilmut and his team announced their successful cloning of Dolly, the sheep, by transfer of a nucleus from an adult somatic cell. The declaration evoked a dramatic and shocked public response, often without much information or understanding about what embryos really are and with reactions often shaped by genetic hereditarian assumptions.

When James Thomson cultured pluripotent stem cells from human embryos the next year, the news of his accomplishment and the similar work by John Gearhart fell on a public already full of assumptions about what cloning meant. The public discussion, including in leading news media, was disappointing in its lack of understanding of what embryos are and how developmental processes work. This led to entrenchment around many of the already existing views rather than a challenging of underlying assumptions.

Now, however, it is hard to remain complacent. We know that researchers can take cells from different mouse embryos, combine them, and develop chimeras that lead to apparently healthy adults. We even know that this happens occasionally in humans, with accidental and "natural" chimerism. And we know that it is possible to use various techniques for recombining DNA to alter the genetic makeup of an embryo. Or we can remove whole cells and still have a healthy birth. What is newest is the ability to hollow out a cell and fill it synthetically with other material. Nobody has created a fully functioning cell quite yet, but many researchers are confident that it will not be long before somebody (perhaps Craig Venter) will do so.

When we can create, recombine, repackage, and synthesize, then what is an "embryo"? It makes sense to stick with the traditional definition captured in the first Encyclopedia Britannica: "Embrio, in physiology, the first rudiments of an animal in the womb, before the several members are distinctly formed; after which period it is denominated a foetus." This was, in effect, the Aristotelian, Catholic, Jewish, and Islamic view for centuries. It works and it embraces the idea of an 
embryo as emerging gradually and in response to the mix of internal, inherited, and responsive factors. Furthermore, if an embryo is understood biologically as not being formed with its parts and functions in place until it becomes a fetus after the eight-week stage, we might be able to begin a serious social and political discussion that is consistent with the scientific facts. We could decide that different protections for fetuses and embryos make good sense, and so do different understandings of and responses for different developmental stages. Such a view would be scientifically defensible, socially wise, and might allow us to bring the various competing views into harmony again.

\author{
Jane Maienschein \\ Center for Biology and Society \\ Arizona State University \\ Tempe, AZ 85287-4501 \\ Marine Biological Laboratory \\ Woods Hole, MA 02543 \\ maienschein@asu.edu
}

\title{
References
}

Bowler, Peter. 1971. Preformation and pre-existence in the Seventeenth Century: A Brief Analysis. Journal of the History of Biology 4: 221-44. doi:10.1007/BF00138311

Churchill, Frederick. 1968. August Weismann and a Break from Tradition. Journal of the History of Biology 1: 91-112. doi:10.1007/BF00149777

Franklin, Sarah. 2007. Dolly Mixtures: The Remaking of Genealogy. Durham, NC: Duke University Press.

Gurdon, J. B. and Alan Colman. 1999. The Future of Cloning. Nature 402: 743-46. doi:10.1038/45429

Hopwood, Nick. 2000. Producing Development: The Anatomy of Human Embryos and the Norms of Wilhelm His. Bulletin of the History of Medicine 74: 29-79.

Maienschein, Jane. 1991. The Origins of Entwicklungsmechanik. In A Conceptual History of Modern Embryology, ed. Scott Gilbert, 43-61. New York: Plenum.

Maienschein, Jane. 2003. Whose View of Life. Embryos, Cloning, and Stem Cells. Cambridge, MA: Harvard University Press.

Maienschein, Jane, and Karen Wellner. [forthcoming 2011]. Competing Views of Embryos. Science and Education.

Mintz, Beatrice. 1964. Formation of Genetically Mosaic Mouse Embryos, and Early Development of 'Lethal (t12/t12)-Normal' Mosaics. The Journal of Experimental Zoology 157 (November): 273-92. doi:10.1002/jez.1401570210

Pauly, Philip. 1996. How did the Effects of Alcohol on Reproduction Become Scientifically Uninteresting? Journal of the History of Biology 29: 1-28. 
J. Maienschein Why Do Stem Cells Create Such Public Controversy?

Roe, Shirley. 1981. Matter, Life, and Generation. Cambridge: Cambridge University Press. Stevens, Leroy. 1970. The Development of Transplantable Teratocarcinomas from Intratesticular Grafts of Pre- and Post-implantation Mouse Embryos. Biology 21: 364-82. doi:10.1016/0012-1606(70)90130-2

Wellner, Karen. 2010. From Fertilization to Birth: Representing Development in High School Biology Textbooks. Master's thesis, Arizona State University. 